\title{
India to Global Epidemiological status on COVID-19: An Update on Genomic Origin \& Phylogenetic study on SARS-CoV2
}

\author{
Murugan $\mathrm{N}^{1 *}$, Jansi $\mathbf{R S}^{2}$, Giridharan $\mathrm{A}^{1}$ and Saravana Kumar $\mathrm{P}^{3}$ \\ ${ }^{1}$ Molecular Genetics, Life Cell International Pvt Ltd, India \\ ${ }^{2}$ Department of Bioinformatics, Stella Maris College, India \\ ${ }^{3}$ CAS Key Laboratory of Tropical Marine Bio-resources and Ecology, Guangdong Key Laboratory \\ of Marine Materia Medica, South China Sea Institute of Oceanology, Chinese Academy of \\ Sciences, Guangzhou, China
}

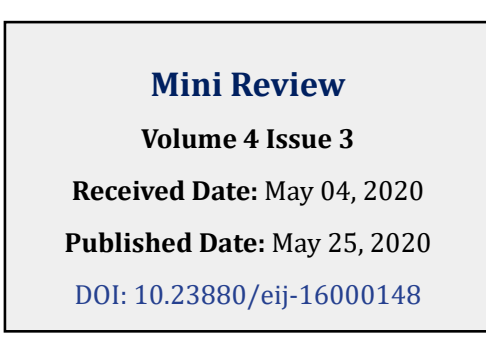

*Corresponding author: Murugan N, Molecular Genetics, 26, Life Cell International Pvt Ltd, Vandalur Kelambakkam Main Road, Keelakottaiyur, Chennai 600048, Tamil Nadu, India, Tel: 9840285436; Email: murugan2science@gmail.com; murugan.n@ fetomed.in

\section{Abstract}

The pandemic spread of novel coronavirus, (SARS-CoV-2) causing CoronaVirus Infectious Diseases (COVID-19) emerged into a global threat for human life causing serious mortality rate and economic crunches worldwide. On April 25, 2020 at 2:00am Central European Summer Time (CEST), WHO reported a total of 2,804,796 confirmed Corona cases and 1, 93, 722 Corona deaths worldwide in 213 countries. In which USA tops 8, 607, 72 confirmed cases (44, 053 deaths) followed by Italy 1, 92, 994 $(25,969$ deaths) and Spain 2, 19, 764 (22, 524 deaths). This study aims to compare the genomic nature of SARS-CoV-2 genome reported from Wuhan, China with two Indian isolate genome reported by ICMR-NIV, India. Further evolutionary relationship studies were performed with coronavirus infecting non-human species like bats, duck, and sparrow were compared with Indian isolates and available whole genome sequences of SARS-CoV2 with aid of MegaX. In addition, epidemiological reports on SARS-CoV2 among Worldwide and India centric data were compared from March 25, 2020 to April 25, 2020. The numbers of active cases were increased dramatically in 30 days period studied, highlighted in the current study.

Keywords: Coronavirus; SARS-CoV-2; COVID-19; World Health Organization (WHO); Pandemic; Genomics; Phylogeny

Abbreviations: HCoV: Human Coronavirus; SARS-CoV: Severe Acute Respiratory Syndrome Coronavirus; MERSCoV: Middle East Respiratory Syndrome Coronavirus; WHO: World Health Organization.

\section{Introduction}

Globally, a total of 211 countries, territories or area have been affected by the novel pathogenic Human Coronavirus ( $\mathrm{HCoV}$ ). The novel coronavirus was officially renamed as "SARS-CoV-2" from "2019-nCoV" from 11th February 2020. The disease caused by SARS-CoV-2 was called "CoronaVirus
Infectious Disease 2019" (COVID-19) by WHO. COVID-19 has been declared as a Public Health Emergency of International Concern by the WHO [1]. The virus belongs to Coronaviridae family which consists of single-stranded, non-segmented positive-sense RNA genome of size approximately $26-32 \mathrm{~kb}$ $[2,3]$. To date, six known HCoVs have been identified, namely HCoV-229E, HCoV-NL63, HCoV-OC43, HCoV-HKU1, Severe Acute Respiratory Syndrome Coronavirus (SARS-CoV) and Middle East respiratory syndrome coronavirus (MERS-CoV); except SARS and MERS, other four were universally dispersed in the human population and causes common cold infections among one-third of human populations [4,5]. 


\section{Epidemiology International Journal}

So far two serious coronavirus disease outbreaks were occurred in the past two decades. First is SARS In 2003, SARS originated from Southern China and spread to more than 30 countries and all major continents, resulted in more than 8000 human infections and 774 deaths [6,7]. The second include MERS in 2012 a genetically different MERS from SARS-CoV which infected 2,249 people in 27 countries with $35 \%$ case fatality $[8,9]$.

The current COVID-19 entirely made the globe into lockdown with the highest death rates and infection rates are changing dynamically every day. The beginning of SARSCoV-2 was linked to a cluster of patients with pneumonia of unknown aetiology connected to a local Huanan South China Seafood Market in Wuhan, Hubei Province, China in December 2019 [10]. It is now emerged as pandemic condition and World Health Organization (WHO) reported on April 27, 2020 at 2:00am CEST, a total of 2,858,635 confirmed cases for Corona and 1,96,295 deaths worldwide which includes 213 countries, areas or territories with cases [1] .

The fuss about the source of the virus and its intermediate host is still not yet confirmed. However, so far, there are still controversies about the source of the virus and its intermediate host [3]. The evolutionary analysis shows that the present strain of coronavirus is more similar to Bat coronavirus isolate RaTG13 (GenBank No.: MN996532.1), with $96.2 \%$ nucleotide homology in the whole genome [1113]. Other groups suggest that pangolin, mink, snake and turtle may be potential intermediate hosts for the virus but not conclusively [3,14-17].

In India, from January 25 to 31, 2020 three cases were shown to be positive for COVID-19 at Kerala state, all the three had travel history from Wuhan, China. Two patient's samples were analyzed by Next Generation sequencing and the data have been published deposited in NCBI under the accession number MT012098.1 and MT050493.1; GISAID database, accession numbers EPI ISL 413522 and EPI ISL 413523 and they reported briefly on various aspects [18]. We initiated our analysis, once the genome sequence was available at the NCBI database, however, Pragya D, et al., reported by the end of March 2020. This study was aimed to understand the genomics and epidemiology of the Indian Human coronavirus with other major countries genome sequence. In addition, the phylogeny relationship between SARS-CoV-2 from Indian patient's genome with other Coronavirus genome which infects other species like Bats, Duck, Sparrow and etc., were also compared.

\section{Materials and Methods}

\section{Sequence Recovery and Analysis}

Genomic sequences hold innumerable information to foresee identification, location and pathogenicity of viral strains. As on April 07, 2020 there stay 547 nucleotide sequences and 5,364 protein sequences available in NCBI Virus database (https://www.nih.gov/coronavirus). Of which 469 sequences contains nearly about $\sim 28000-29000$ base pairs (bps), sequences represents complete genome data and 78 denotes short specific protein encoding gene sequences.

The phylogeny was constructed to compare the evolutionary relationship of human and bat genome sequences. We used the first complete genome sequence submitted by China under the Genbank id: NC_045512.2 for Severe acute respiratory syndrome coronavirus 2 (SARSCoV-2) [COVID-19] for the study and a BLAST similarity search was performed. The top 100 hits were screened and the aligned sequences were selected for further studies. Genome sequences of novel COVID-19 affecting Human (30) including 2 genome from India-Kerala state MT050493.1 \& MT012098.1 and 2 closely related bat corona viral genomes MG772933.1 and MN996532.1 were investigated using MEGAX. The sequences were subjected to analysis by Maximum Likelihood method and Tamura-Nei model for the native and bootstrap tree (50 repeats) construction.

To compare the genomic evolutionary lineage from the other species, we compared six (6) sequences of SARS-CoV-2 [Genbank id: NC_045512.2, MT126808.1, MT007544.1, MT049951.1, MT012098.1 (India) and MT050493.1 (India)] and 24 corona virus isolates from other species such as bat, sparrow, duck, pig, cow, etc., using MEGA X [19-21] (Table 1).

\begin{tabular}{|c|c|c|c|c|c|}
\hline Accession & Species & Genus & Length & Host & GenBank Title \\
\hline AY515512 & $\begin{array}{c}\text { Severe acute } \\
\text { respiratory syndrome- } \\
\text { related coronavirus }\end{array}$ & Betacoronavirus & 29731 & $\begin{array}{c}\text { Paguma } \\
\text { larvata }\end{array}$ & SARS coronavirus HC/SZ/61/03 \\
\hline AY572038 & $\begin{array}{c}\text { syndrome- } \\
\text { related coronavirus }\end{array}$ & Betacoronavirus & 29683 & civet & SARS coronavirus civet020 \\
\hline
\end{tabular}


Epidemiology International Journal

\begin{tabular}{|c|c|c|c|c|c|}
\hline EF065511 & $\begin{array}{c}\text { Pipistrellus bat } \\
\text { coronavirus HKU5 }\end{array}$ & Betacoronavirus & 30488 & Chiroptera & Bat coronavirus HKU5-3 \\
\hline JF705860 & Avian coronavirus & Gammacoronavirus & 27673 & Anatidae & $\begin{array}{l}\text { Duck coronavirus isolate DK/CH/ } \\
\text { HN/ZZ2004 }\end{array}$ \\
\hline JN874560 & $\begin{array}{c}\text { Rabbit coronavirus } \\
\text { HKU14 }\end{array}$ & Betacoronavirus & 31116 & $\begin{array}{l}\text { Oryctolagus } \\
\text { cuniculus }\end{array}$ & $\begin{array}{l}\text { Rabbit coronavirus HKU14 strain } \\
\text { HKU14-3 }\end{array}$ \\
\hline JQ065044 & $\begin{array}{c}\text { White-eye coronavirus } \\
\text { HKU16 }\end{array}$ & Deltacoronavirus & 26041 & Zosteropidae & $\begin{array}{l}\text { White-eye coronavirus HKU16 } \\
\text { strain HKU16-6847 }\end{array}$ \\
\hline KJ473806 & \begin{tabular}{|c|} 
Myotis ricketti \\
alphacoronavirus Sax- \\
2011 \\
\end{tabular} & Alphacoronavirus & 27935 & Myotis ricketti & BtMr-AlphaCoV/SAX2011 \\
\hline KJ473809 & $\begin{array}{c}\text { Nyctalus velutinus } \\
\text { alphacoronavirus SC- } \\
2013 \\
\end{array}$ & Alphacoronavirus & 27783 & $\begin{array}{l}\text { Nyctalus } \\
\text { velutinus }\end{array}$ & BtNv-AlphaCoV/SC2013 \\
\hline KJ473821 & \begin{tabular}{|c|} 
Middle East \\
respiratory syndrome- \\
related coronavirus
\end{tabular} & Betacoronavirus & 30423 & $\begin{array}{l}\text { Vespertilio } \\
\text { sinensis }\end{array}$ & BtVs-BetaCoV/SC2013 \\
\hline KM454473 & Avian coronavirus & Gammacoronavirus & 27754 & Anatidae & $\begin{array}{c}\text { Duck coronavirus isolate DK/ } \\
\text { GD } / 27 / 2014\end{array}$ \\
\hline KX185057 & Avian coronavirus & Gammacoronavirus & 27802 & Gallus gallus & $\begin{array}{l}\text { Infectious bronchitis virus strain } \\
\text { ck/CH/LHLJ/95I }\end{array}$ \\
\hline KX432213 & Betacoronavirus 1 & Betacoronavirus & 30868 & $\begin{array}{l}\text { Canis lupus } \\
\text { familiaris }\end{array}$ & $\begin{array}{l}\text { Canine respiratory coronavirus } \\
\text { strain BJ232 }\end{array}$ \\
\hline KX499468 & Alphacoronavirus 1 & Alphacoronavirus & 28614 & Sus scrofa & $\begin{array}{c}\text { Transmissible gastroenteritis virus } \\
\text { strain TGEV AHHF }\end{array}$ \\
\hline KY994645 & Betacoronavirus 1 & Betacoronavirus & 30684 & Sus scrofa & $\begin{array}{c}\text { Porcine hemagglutinating } \\
\text { encephalomyelitis virus strain } \\
\text { JL/2008 }\end{array}$ \\
\hline MH810163 & Betacoronavirus 1 & Betacoronavirus & 31032 & Bos grunniens & $\begin{array}{c}\text { Yak coronavirus strain YAK/HY24/ } \\
\text { CH/2017 }\end{array}$ \\
\hline MK211369 & $\begin{array}{l}\text { Coronavirus BtSk- } \\
\text { AlphaCoV/GX2018A }\end{array}$ & Alphacoronavirus & 28303 & $\begin{array}{l}\text { Scotophilus } \\
\text { kuhlii }\end{array}$ & $\begin{array}{c}\text { Coronavirus BtSk-AlphaCoV/ } \\
\text { GX2018A }\end{array}$ \\
\hline MK423876 & Avian coronavirus & Gammacoronavirus & 27655 & Phasianinae & $\begin{array}{c}\text { Pheasant coronavirus strain } \\
\text { gammaCoV/ph/China/I0710/17 }\end{array}$ \\
\hline MK720944 & $\begin{array}{c}\text { Tylonycteris bat } \\
\text { coronavirus HKU33 }\end{array}$ & Alphacoronavirus & 27636 & $\begin{array}{l}\text { Tylonycteris } \\
\text { robustula }\end{array}$ & $\begin{array}{c}\text { Tylonycteris bat coronavirus } \\
\text { HKU33 strain GZ151867 }\end{array}$ \\
\hline MN611520 & $\begin{array}{c}\text { Pipistrellus abramus } \\
\text { bat coronavirus HKU5- } \\
\text { related }\end{array}$ & Betacoronavirus & 30511 & $\begin{array}{l}\text { Pipistrellus } \\
\text { abramus }\end{array}$ & $\begin{array}{c}\text { Pipistrellus abramus bat } \\
\text { coronavirus HKU5-related isolate } \\
\text { BY140568 } \\
\end{array}$ \\
\hline NC_016992 & $\begin{array}{c}\text { Sparrow coronavirus } \\
\text { HKU17 } \\
\end{array}$ & Deltacoronavirus & 26083 & Passeridae & Sparrow coronavirus HKU17 \\
\hline MK907287 & $\begin{array}{l}\text { Erinaceus hedgehog } \\
\text { coronavirus HKU31 }\end{array}$ & Betacoronavirus & 29951 & $\begin{array}{l}\text { Erinaceus } \\
\text { amurensis }\end{array}$ & $\begin{array}{c}\text { Erinaceus hedgehog coronavirus } \\
\text { HKU31 strain Rs13 }\end{array}$ \\
\hline KX981440 & $\begin{array}{l}\text { Porcine epidemic } \\
\text { diarrhea virus }\end{array}$ & Alphacoronavirus & 28124 & Sus scrofa & $\begin{array}{l}\text { Porcine epidemic diarrhea virus } \\
\text { isolate } \mathrm{CH} / \mathrm{HNZZ47/2016}\end{array}$ \\
\hline
\end{tabular}




\section{Epidemiology International Journal}

\begin{tabular}{|c|c|c|c|c|c|}
\hline MN611521 & $\begin{array}{c}\text { Scotophilus kuhlii } \\
\text { bat coronavirus } \\
\text { 512-related } \\
\end{array}$ & Alphacoronavirus & 27933 & $\begin{array}{l}\text { Scotophilus } \\
\text { kuhlii }\end{array}$ & $\begin{array}{l}\text { Scotophilus kuhlii bat coronavirus } \\
\text { 512-related isolate HK140714 }\end{array}$ \\
\hline MN996532 & Bat coronavirus & Betacoronavirus & 29855 & $\begin{array}{l}\text { Rhinolophus } \\
\text { affinis }\end{array}$ & Bat coronavirus RaTG13 \\
\hline NC_045512 & $\begin{array}{l}\text { Severe acute } \\
\text { respiratory syndrome } \\
\text { coronavirus } 2\end{array}$ & Betacoronavirus & 29903 & Homo sapiens & $\begin{array}{c}\text { Wuhan seafood market pneumonia } \\
\text { virus isolate Wuhan-Hu-1 }\end{array}$ \\
\hline MT049951 & $\begin{array}{l}\text { Severe acute } \\
\text { respiratory syndrome } \\
\text { coronavirus } 2\end{array}$ & Betacoronavirus & 29903 & Homo sapiens & $\begin{array}{l}\text { SARS-CoV-2/Yunnan-01/ } \\
\text { human/2020/CHN }\end{array}$ \\
\hline MT126808 & $\begin{array}{l}\text { Severe acute } \\
\text { respiratory syndrome } \\
\text { coronavirus } 2\end{array}$ & Betacoronavirus & 29876 & Homo sapiens & $\begin{array}{c}\text { SARS-CoV-2/SP02/human } / 2020 / \\
\text { BRA }\end{array}$ \\
\hline MT050493 & $\begin{array}{l}\text { Severe acute } \\
\text { respiratory syndrome } \\
\text { coronavirus } 2\end{array}$ & Betacoronavirus & 29851 & Homo sapiens & $\begin{array}{c}\text { SARS-CoV-2/166/human/2020/ } \\
\text { IND }\end{array}$ \\
\hline MT012098 & $\begin{array}{c}\text { Severe acute } \\
\text { respiratory syndrome } \\
\text { coronavirus } 2 \\
\end{array}$ & Betacoronavirus & 29854 & Homo sapiens & SARS-CoV-2/29/human/2020/IND \\
\hline MT007544 & $\begin{array}{l}\text { Severe acute } \\
\text { respiratory syndrome } \\
\text { coronavirus } 2\end{array}$ & Betacoronavirus & 29893 & Homo sapiens & $\begin{array}{l}\text { SARS-CoV2 isolate Australia/ } \\
\text { VIC01/2020 }\end{array}$ \\
\hline
\end{tabular}

Table 1: Genbank accession and details of Corona virus affecting other species genomes used in this study.

\section{Results}

A phylogenetic tree was constructed with 30 genome sequences of Human coronavirus and 3 sequences of bat coronavirus. The algorithm produced a tree with highest log likelihood value (-632944.00) and also formed a bootstrap consensus tree inferred from 50 replicates. The percentage of trees in which the associated taxa clustered together was shown next to the branches. There were a total of 29903 positions in the final dataset. The lengths of the branches represent the amount of change that is estimated to have occurred between a pair of nodes. Alternative evolutionary trees are produced by bootstrapping analysis under maximum likelihood model. This is done through 50 iterations and when we recover the same node after 50 iterations then the node in the tree is well supported.

Upon boostrap, (Figure 1A) showed all the three BatSARS-like coronavirus in closed group branching to the China, USA and India strains. Though the first complete genome NC045512.2.1-29903 Wuhan-Hu-1 (blue triangle) was closely branched to MN996528.1 [Wuhan, Hubei, China], MT093571.1 [Sweden], MT039890.1 [Korean travelled from Wuhan, China], MT066156.1 [First case of Italy], MT007544.1
[Australia], the Bat SARS virus, precisely RaTG13 and SLCovzc45 were completely close and neighborhood with the CoVid-19 isolated from Wuhan-genomes MT198652.2 (Spain), MT123292.2 (Guangzhou, China) MT012098.1 (Kerala, India) and LR757995.1 (Hong Kong, China).

The purpose of this study is to highlight the key role of Wuhan, China trace to Indian patients. Hence, the two Indian-Kerala state isolates were specifically traced by multiple alignments of the genome sequences using NCBI tool and Multalin, we found MT012098 consist of 29,854 bps and MT050493.1 consist of 29, 851bps, three base pairs were missing in the initial sequence of the second isolate. Whereas totally, 9 point mutations were identified in this two genomes of which, 8 were C-T/T-C change and only one mutation at position $22,772 \mathrm{~T} / \mathrm{G}$ change with $99 \%$ identity score. The point mutation between two Indian isolates MT012098 and MT050493 were at nine positions as follows, $6488 \mathrm{C} / \mathrm{T}, 6682 \mathrm{~T} / \mathrm{C}, 8769 \mathrm{C} / \mathrm{T}, 14644 \mathrm{~T} / \mathrm{C}, 16864 \mathrm{C} / \mathrm{T}, 17360$ T/C, $22772 \quad \mathrm{~T} / \mathrm{G}, 24338 \mathrm{C} / \mathrm{T}, 28131 \mathrm{~T} / \mathrm{C}$. The second strain from India MT050493.1 was in close association with LR757996.1 (Wuhan, China), MN938384.1 (Guangdong, China) and LC528232.1 (Isolated from a patient in cruise ship, Japan). 


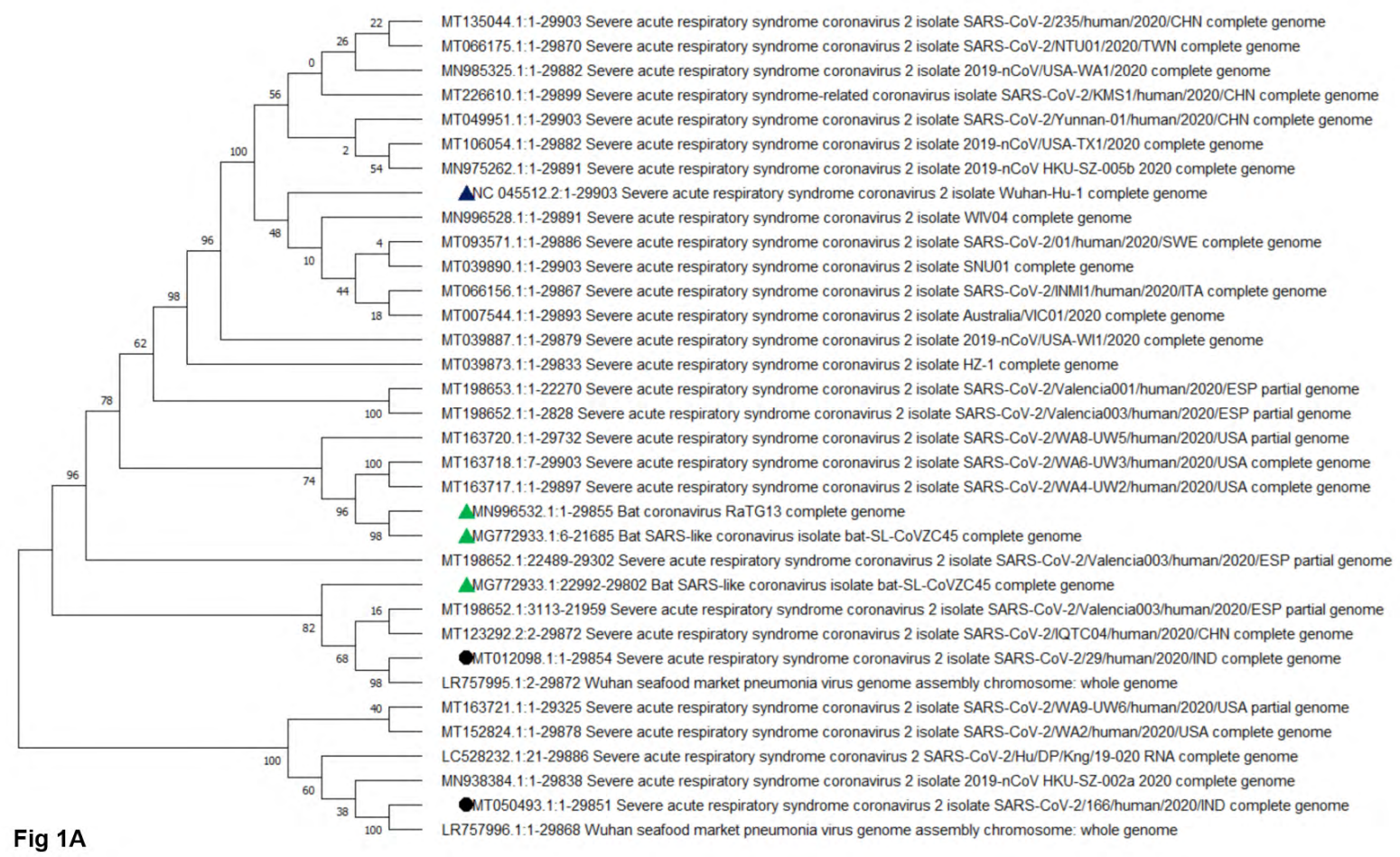

Figure 1A: Phylogenetic tree (Bootstrap) of the complete genomes of severe acute respiratory syndrome coronavirus 2 viruses. SARS-CoV2 isolated from Indian patient was shown in black circle.

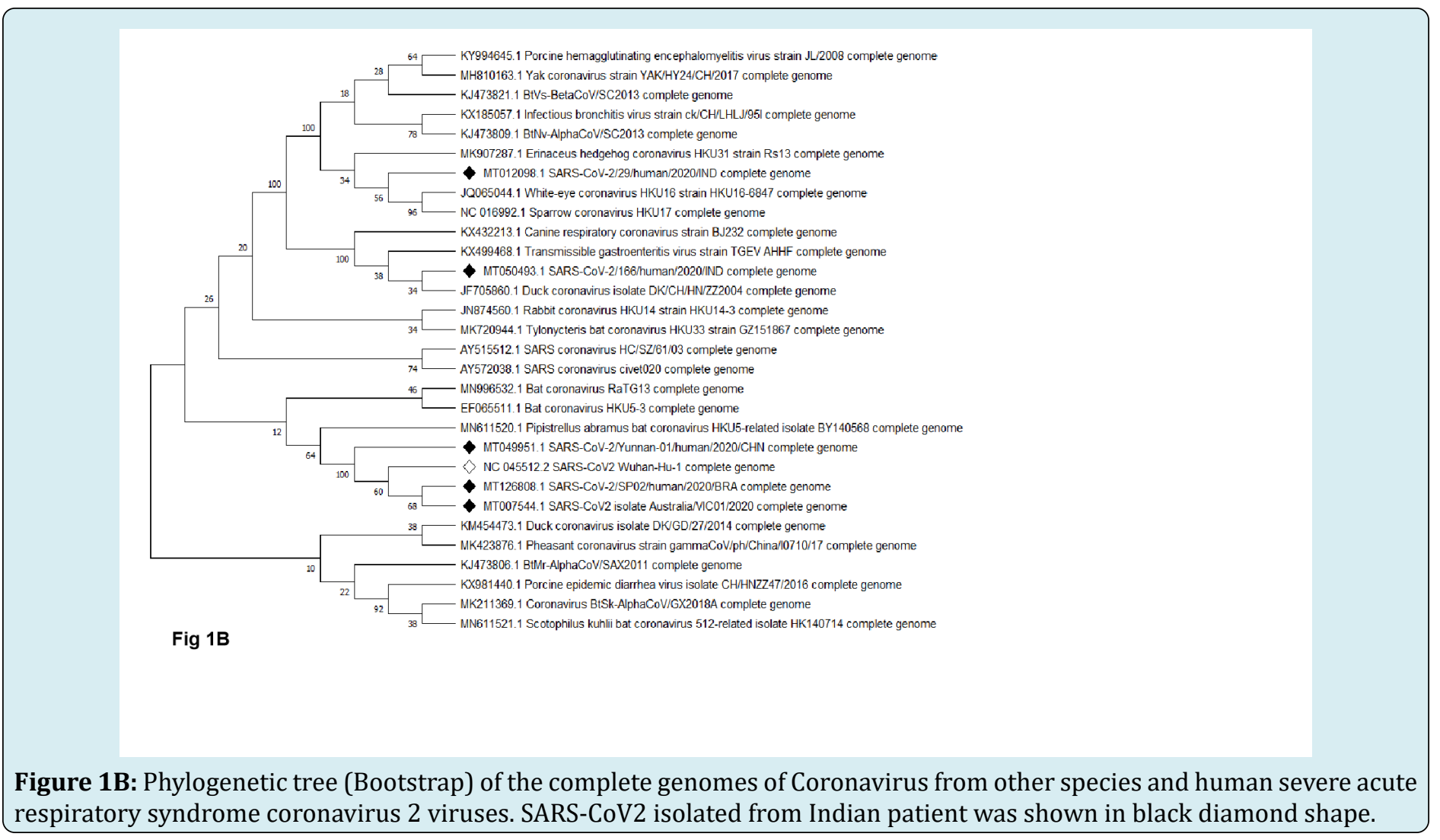




\section{Epidemiology International Journal}

Phylogenic study of coronavirus genome with diverse organisms showed, highest log likelihood value of -1064822.43 along with bootstrap consensus tree of 50 replicates. In this analysis a total of 31116 positions in the final dataset were used. Though two Coronavirus from Indian patient had history from Wuhan travel and returned to India, Kerala state. Human corona virus (MT012098.1) is closely related to White-eye coronavirus (JQ065044.1) and sparrow coronavirus (NC016992.1). The second Indian human coronavirus genome (MT050493.1) was closely related to Duck coronavirus (JF705860), Transmissible gastroenteritis (KX499468.1) and Canine respiratory coronavirus (KX432213.1). Whereas, all the other human affecting coronavirus genome from China, Wuhan, Brazil, Australia were closely related and they were adjacent to Bat coronavirus (MN996532.1, EF065511.1, MN611520.1), civet coronavirus AY572038.1 as a secondary neighborhood close to the human coronavirus next to bat virus (Figure 1B). Though it is not conclusive, the coronavirus from sparrow and white-eye are more close to Indian isolates, which indicates they may be associated with the patients from other species of animal sources.

\section{Discussion}

The emergence and rapid spread of COVID-19 signifies a perfect epidemiological storm. COVID-19 a member of the genus Beta coronavirus, subgenus Sarbecovirus as like SARS$\mathrm{CoV}$, but MERS-CoV belongs to the subgenus Merbecovirus $[11,22-23]$. The RaTG13 is $96 \%$ identical to COVID-19 at the nucleotide level, but the receptor binding domain (RBD) is only $85 \%$ similar and shared only one of the six critical amino acid residues [24]. Still, the COVID-19 RBD for human ACE2 receptor found to be strong and functional [25] which armor the virus towards human respiratory system.

A research Group of South China Agricultural University analyzed more than 1,000 met genomic samples, and they found $70 \%$ of pangolins were positive for the coronavirus. In addition, virus isolate from pangolin shared $99 \%$ sequence similarity with the current infected human strain SARSCoV-2 [26] and they addressed pangolins may be one of the intermediate hosts for SARS-CoV-2 later they were embrassed to be a miscommunication of data reported [27] In fact, only $90 \%$ genome were homology to SARS-CoV-2 genome and Coronavirus from Pangolins. This incidence was a best example, how the scientific and public media were exaggerating the data without solid evident.

In spite, the $96 \%$ identity of SARS-CoV-2 with the Bat coronavirus presumes, they are very closely related to SARSCoV- 2, in virtual this likely represents more than 20 years of RNA sequence evolution, which may occur if the molecular clock emerges at an uncertain rate if there was strong adaptive evolution of the virus in humans [24]. Available bat coronavirus genome was studied from Yunnan province, over 1,500 km from Wuhan. There are few bat coronaviruses from Hubei province, and those that have been sequenced are relatively distant to SARS-CoV-2 in phylogenetic trees [28]. The available data on bat viruses is strongly biased toward some geographical locations, which needs further study [24].

The two Indian SARS-CoV-2 sequences were found to be non-identical $(0.04 \%$ nt divergence), and the result of phylogenetic analysis indicated they are not in same clade, carries two different lineage which indicates they are nonidentical source of infection [18]. Further multiple genomes sequencing of Coronavirus from Indian patients will give us better understanding about the source of infection and mutation rate among the patients and point of contact. The phylogenetic analysis of two Indian isolates elucidates strong association with Bat virus genome, inspite the close association with duck and sparrow coronavirus were double checked with the genome blast given no statistical significance. Inspite, we estimate, if new coronavirus genome sequence from other animals like Bats, Pangolin, Civet or any other animal associated with Huanan South China Seafood Market in Wuhan, Hubei Province, China, may give us solid source of infection and the mode of transmission from animal to Human can be traced. Since, the $3-3.95 \%$ genome difference in RNA virus between SARS-CoV-2 and RaTG13 will not happen in a year and we are lacking the exact source or primary host of this novel coronavirus.

In India, as on April 27, 2020 19:51 IST, totally 28,255 confirmed cases; 6720 recovered cases, 20,647 active cases and 888 deaths (https://www.covid19india.org/). Currently, Maharastra, Guarat, Delhi and Rajasthan are the top-most three affected States of India. Despite, India had cases from Wuhan to India-Kerala state by January 4 th week 2020, the cases gradually were increased and identified from patients with travel history of various other countries and regions. In India, COVID-19 positive age group belongs to 31-40 in top (22.88\%) among the Indian population followed by 21-30 age group (22.03\%), 41-50 (16.32\%); 51-60 (13.04\%), 1120 (9.71\%), 61-70 (8.69\%), 0-10 (4.18\%), 81-90 (0.43\%),91$100(0.13 \%)$ (Figure 2A). Compared to worldwide data, Indian data shows the number of cases high among 31-50 age group, when 60-80 age group in other countries. The reason behind this age difference must be studied further to estimate the scientific root cause. In addition, gender difference indicates of the 5,313 patients data available $3,547(66.8 \%)$ belongs to male and $1,776(33.2 \%)$ female (Figure 2B). This gender difference is concordant with data from various other countries. 


\section{Epidemiology International Journal}
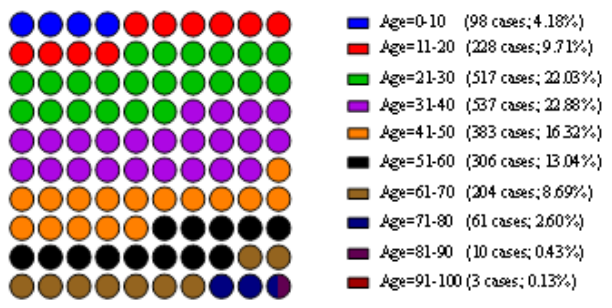

Figure 2A: Graphical representation of Age and Gender wise confirmed cases among Indian patients; 2(A) Age wise confirmed cases; The circles were filled with respective colors according to their percentage given in the data (Total sample-2,344).

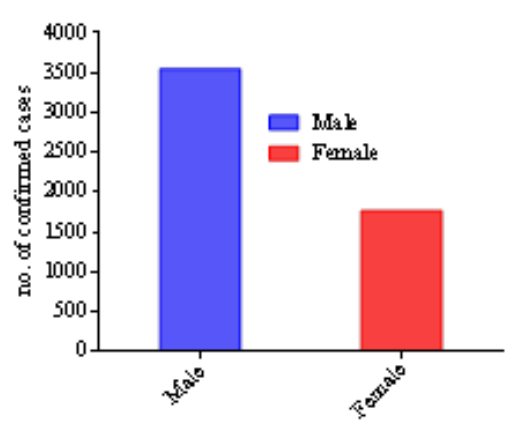

Figure 2(B): Gender wise confirmed cases (Total sample-5,313) (data obtained from https://www. covid19india.org/ as on April 27, 2020).
The Government of India made complete Lockdown on March 24, 2020 midnight to April 15, 2020 early morning (21 days) as a first schedule. Second schedule announced by Honorable Prime Minister of India Mr. Narendra Modi on April 14th $10 \mathrm{am}, 2020$ that the lockdown will be extended further to stop the spread of COVID-19 from local transmission (stage 2) to community transmission (stage 3) from April 15 early morning to May 3, 2020 early morning. This will further reduce the number of new infection rate, and the existing patients may be identified and treated according to the WHO guidelines. In spite of all the effort taken, the rate of new cases has been steeply increased over April 3rd week and the list of confirmed, dead and recovered details shown in the Table 2. Since, the lockdown has been initiated early when the number of confirmed cases was just 571 on March 24,2020 . India has controlled its number of cases till data (April 27,2020) to below 30,000 confirmed cases, whereas, Country like USA has not followed strict lockdown at the earlier stage addressing the increased confirmed cases and death toll. But this is not an end, anytime it can shoot up in India, as the number of asymptomatic carriers who were not diagnosed officially, may walkthrough community when the lockdown revoked, it may slowly increase the number of cases among highly populated area like metropolitan cities in India. Following social distancing, wearing mask and maintaining hygienic practices only can help India to success this pandemic situation.

\begin{tabular}{|c|c|c|c|c|c|}
\hline Position & State/UT & Confirmed & Active & Recovered & Deceased \\
\hline 1 & Maharashtra & 8,068 & 6,538 & 1,188 & 342 \\
\hline 2 & Gujarat & 3,301 & 2,837 & 313 & 151 \\
\hline 3 & Delhi & 2,918 & 1,987 & 877 & 54 \\
\hline 4 & Rajasthan & 2,234 & 1,519 & 669 & 46 \\
\hline 5 & Madhya Pradesh & 2,090 & 1,685 & 302 & 103 \\
\hline 6 & Tamil Nadu & 1,937 & 812 & 1,101 & 24 \\
\hline 7 & Uttar Pradesh & 1,873 & 1,516 & 327 & 30 \\
\hline 8 & Andhra Pradesh & 1,177 & 911 & 235 & 31 \\
\hline 9 & Telangana & 1,001 & 660 & 316 & 25 \\
\hline 10 & West Bengal & 649 & 524 & 105 & 7 \\
\hline 11 & Jammu and Kashmir & 546 & 375 & 164 & 19 \\
\hline 12 & Karnataka & 512 & 300 & 193 & 4 \\
\hline 13 & Kerala & 482 & 123 & 355 & 2 \\
\hline 14 & Bihar & 345 & 287 & 56 & 19 \\
\hline
\end{tabular}




\section{Epidemiology International Journal}

\begin{tabular}{|c|c|c|c|c|c|}
\hline 16 & Haryana & 301 & 85 & 213 & 3 \\
\hline 17 & Odisha & 111 & 75 & 35 & 1 \\
\hline 18 & Jharkhand & 98 & 82 & 13 & 3 \\
\hline 19 & Uttarakhand & 51 & 18 & 33 & - \\
\hline 20 & Chandigarh & 40 & 23 & 17 & - \\
\hline 21 & Himachal Pradesh & 40 & 16 & 22 & 2 \\
\hline 22 & Chhattisgarh & 37 & 5 & 32 & - \\
\hline 23 & Assam & 36 & 8 & 27 & 1 \\
\hline 24 & $\begin{array}{l}\text { Andaman and Nicobar } \\
\text { Islands }\end{array}$ & 33 & 22 & 11 & - \\
\hline 25 & Ladakh & 20 & 4 & 16 & - \\
\hline 26 & Meghalaya & 12 & 11 & - & 1 \\
\hline 27 & Puducherry & 8 & 4 & 4 & - \\
\hline 28 & Goa & 7 & - & 7 & - \\
\hline 29 & Manipur & 2 & - & 2 & - \\
\hline 30 & Tripura & 2 & - & 2 & - \\
\hline 31 & Arunachal Pradesh & 1 & - & 1 & - \\
\hline 32 & Mizoram & 1 & 1 & - & - \\
\hline Total & & 28,255 & 20,647 & 6720 & 888 \\
\hline
\end{tabular}

Table2: Representation of State wise confirmed cases, Active cases, Recovered and Deceased cases as on April 27, 2020 18:55 IST.

Government of India and the health authorities of all the states had taken necessary action to curb spread and made containment plan and enhanced surveillances for the virus and its restricted movement. ICMR-NIV, Pune doing splendid work towards the identification of corona patients through Real-time quantitative PCR and rapid kit based methods. Currently, the diagnoses were carried out for the patients with clinical symptoms and or travel history or their contacts. In near future, the Government has planned to test everyone with symptoms irrespective of travel or contact history. This will curb the case of COVID-19 in India.

The world wide data alarms USA, Italy, Spain, UK, Iran, Netherlands, France and other countries with high rate of death cases, warrants early diagnosis and treatment, though there is no specific drug against COVID-19. The perfect lockdown, social distancing and safety measures plays vital role in this current scenario to reduce the number of new cases arises in the world.

The fold change of confirmed cases and deceased rate in 30 days was drastic escalation among the world and it should be recorded in the literature for future study. Hence, we included the whole data in the Table 3 , and the top 20 countries with death fold increase in 30 days between March 28, 2020 to April 25, 2020 as follows United States of America 98\%, Italy 74\%, Spain $88 \%$, France 95\%, The United Kingdom 98\%, Belgium 98\%, Iran (Islamic Republic of) $63 \%$, Germany $97 \%$, China $29 \%$, Netherlands $94 \%$, Brazil 99\%, Turkey 98\%, Canada 99\%, Sweden 98\%, Switzerland 93\%, Mexico 100\%, Portugal 96\%, Ireland 99\%, India 99\%, Indonesia $92 \%$ (Figure 3A). We suspect the data given by the China is not favour with the other data globally, because every other country had minimum of $63 \%$ (Iran) and maximum of $100 \%$ (Mexico) fold increase in death rate irrespective of number of confirmed cases or deaths occurred in the same period [1], they all concurrence with the global data, whereas, in china it showed lowest death rate of $29 \%$ in the same period, it could be due to the origin of viral spread and the containment effort taken by the Chinese government due to the understanding of seriousness of this COVID-19 at earlier stage would have prevented them from new infective cases or the data may not be authentic as per USA president Mr Donald Trump statement [29-31]. 
Fig.3A

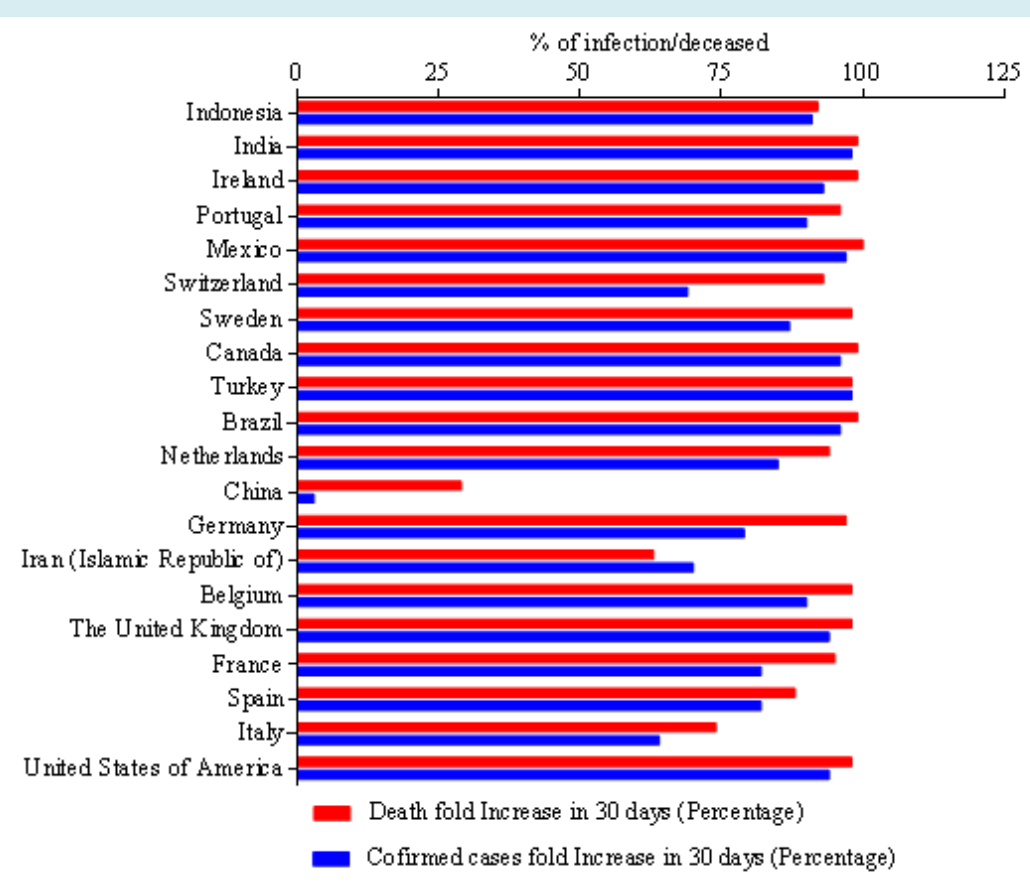

Figure 3A: Representation of top 20 country wise data from March 25, 2020 to April 25, 2020. (3A) confirmed case fold change and Death fold change between March 25, 2020 to April 25, 2020.

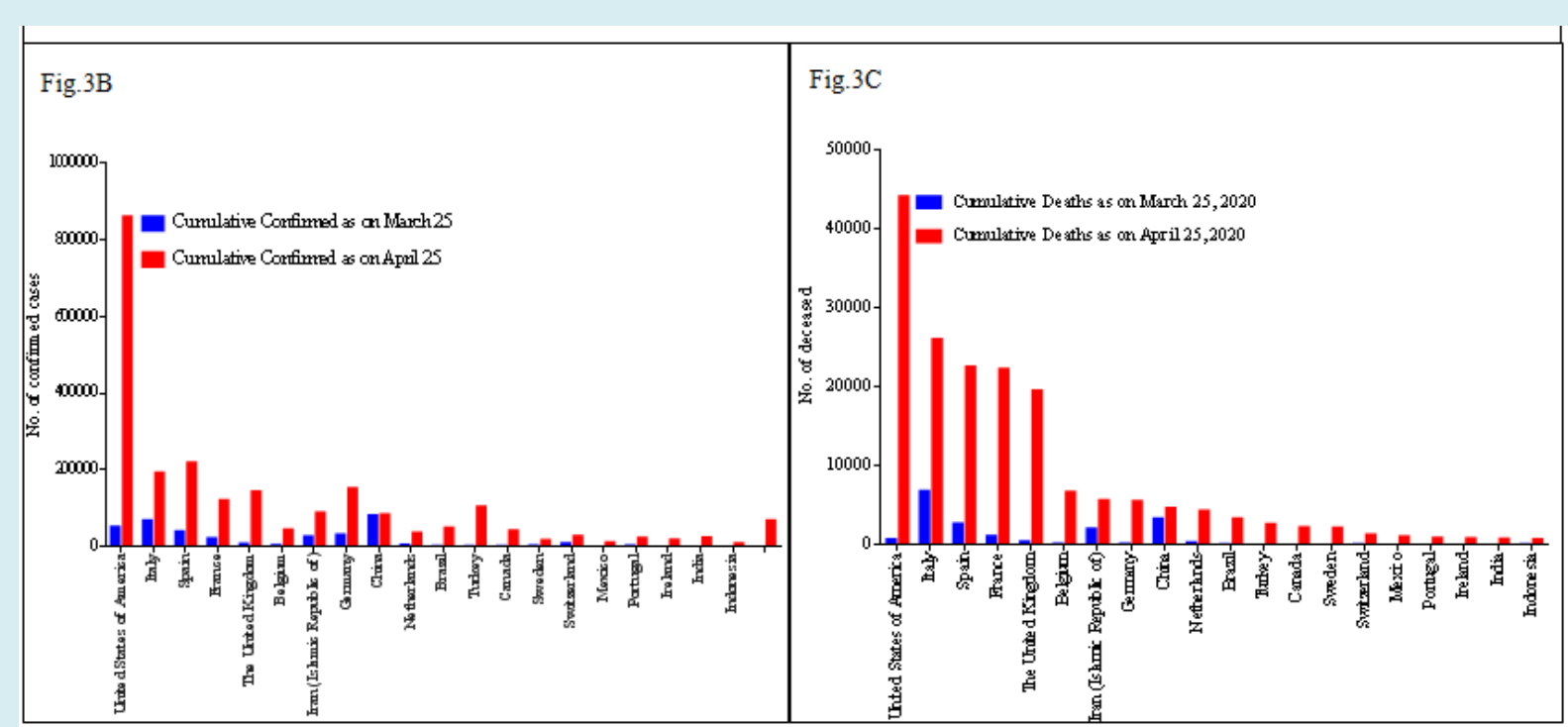

Figure 3B-C: Representation of top 20 country wise number of confirmed case and number of deceased between March 25, 2020 to April 25, 2020 (30 days) as per WHO report.

Inspite of all the effort taken all over the world, USA has been affected to the highest level in the world, where 860772 confirmed cases and 44053 deaths were reported as on April 25, 2020 (Figure 3B-C). Next to USA, the top 9 countries were Italy, Spain, France, The United Kingdom, Belgium, Iran (Islamic Republic of), Germany, China, Netherlands have confirmed cases of 192,994, 219,764, 121,338, 143468,
$44293,89328,152438,84325,36,535$ respectively and the death toll reported to be Italy 25,969, Spain 22,524, France 22,212, The United Kingdom 19,506, Belgium 6679, Iran (Islamic Republic of) 5650, Germany5500, China4642, Netherlands 4289 as per WHO report (April 17,2020 2:00am CEST). Although Germany position to be 4 th as per the confirmed cases, but the number of death reported till date 
was lower compared to other countries, which made it as 9th position. The complete country wise cumulative confirmed cases and cumulative deaths between March 25th 2020 and
April 25th 2020 were calculated and the percentage wise confirmed cases and death rate in 30 days was calculated. WHO region wise data in (Figure 4A-D).

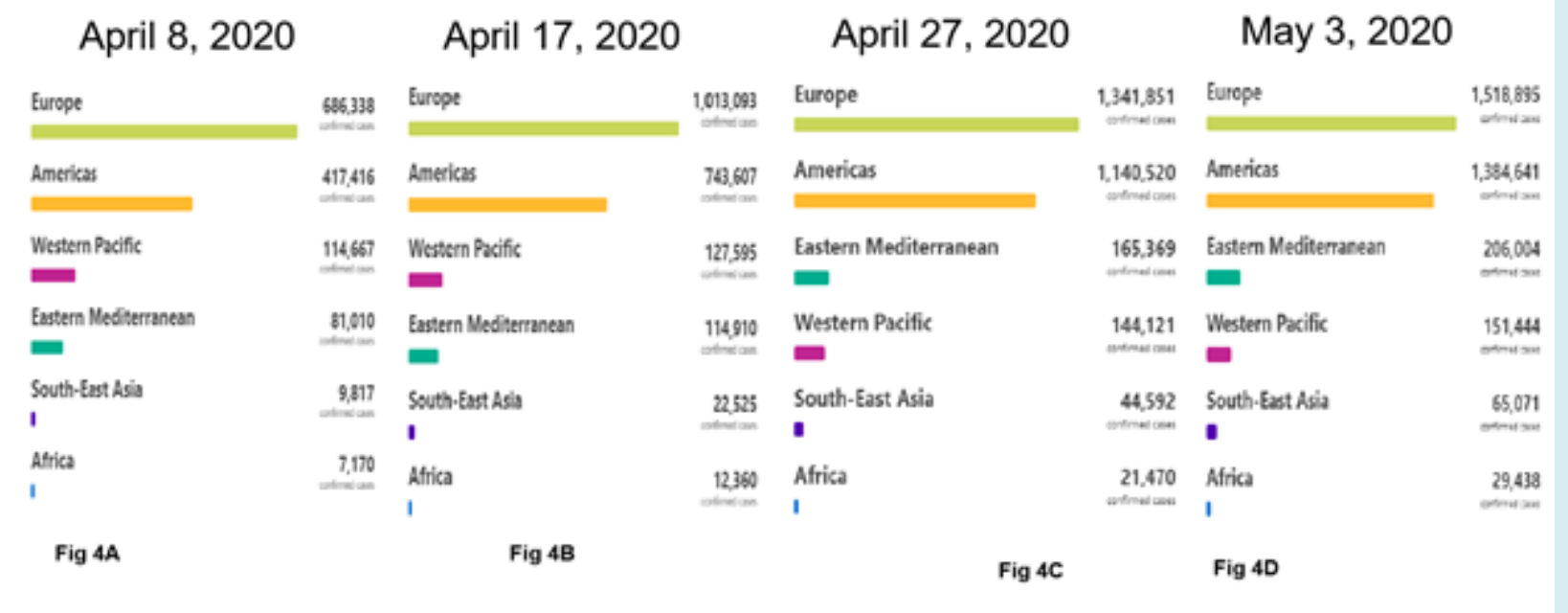

Figure 4A-D: Region wise Confirmed cases as per WHO report as on April 8, 2020 at 2:00am CET and April 17, 2020 at 2:00 am CEST April 27, 2020 at 2:00 am CEST, May 3, 2020 at 2:00 am CEST. [Image taken from WHO report].

Continued testing of people, irrespective of symptoms and travel history is the need of time to scrutinize the asymptomatic carrier people among the group of population, will cut down the number of death rate. April 2020 plays major role in the steady death toll increase among various countries mentioned above. Early diagnosis, appropriate treatment, containment zone formation, Quarantine the people with symptoms may help us to flat the rate of infection and death rate.

\section{Possible Ending of COVID-19}

The pandemic COVID-19 outbreak may have handful different endings. If nature or God give us the luck, the most favourable scenario would be COVID-19 unconsciously petering out as was the case with SARS in 2003. The second chance would be like MERS which, continue sporadically pop up over the years. The third one in worst scenario, it may create more deaths over the year as the sinister path like 1918 Spanish influenza over a decade. Let the nature and future determine it.

\section{Conclusion}

The dynamic increase of number of confirmed cases and genome sequences from all over the world made us to register the various conditions as on April 1st week, 2020. Every one hour, the world wide data has been updated in various resources like WHO, John Hopkins website and Worldometer.
In this context, our study from 2 Indian isolate provided us the trace for infection source and the spread rate increases the point mutation, which may either reduce the virulent or increase the pathogenicity of novel coronavirus, SARS-CoV-2 mediated COVID-19 which needs further studies.

\section{References}

1. World Health Organization (2020) Coronavirus disease (COVID-2019) situation reports. WHO.

2. CuiJ, Li F, Shi ZL (2019) Origin and evolution of pathogenic coronaviruses. Nat Rev Microbiol 17(3): 181-192.

3. Li C, Yang Y, Ren L (2020) Genetic evolution analysis of 2019 novel coronavirus and coronavirus from other species. Infection Genetics and Evolution 82: 104285.

4. Van der Hoek L (2007) Human coronaviruses: What do they cause?. Antivir Ther 12(4): 651-658

5. Lim YX, Ng YL, Tam JP, Liu DX (2016) Human coronaviruses: a review of virus-host interactions. Diseases 4(3): 26.

6. Peiris JS, Yuen KY, Osterhaus AD, Stohr K (2003) The severe acute respiratory syndrome. $\mathrm{N}$ Engl J Med 349(25): 2431-2441.

7. Wang LF, Eaton BT (2007) Bats, civets and the emergence 
of SARS. Curr Top Microbiol Immunol 315: 325-344.

8. Zaki AM, van Boheemen S, Bestebroer TM, Osterhaus AD, Fouchier RA (2012) Isolation of a novel coronavirus from a man with pneumonia in Saudi Arabia. N Engl J Med 367(19): 1814-1820.

9. Middle East respiratory syndrome coronavirus (MERS$\mathrm{CoV}$ ) on World Wide Web URL.

10. Zhu N, Zhang D, Wang W, Li X, Yang B, et al. (2020) A novel coronavirus from patients with pneumonia in China, 2019. N Engl J Med 382: 727-733.

11. Zhou P, Yang XL, Wang XG, Hu B, Zhang L, et al. (2020) A pneumonia outbreak associated with a new coronavirus of probable bat origin. Nature 579(7798): 270-273.

12. Coutard B, Valle C, de Lamballerie X, Canard B, Seidah $N G$, et al. (2020) The spike glycoprotein of the new coronavirus 2019-nCoV contains a furin-like cleavage site absent in CoV of the same clade. Antiviral Res 176: 104742.

13. Jiang S, Shi ZL (2020) The first disease X is caused by a highly transmissible acute respiratory syndrome coronavirus. Virol Sin.

14. Special Expert Group for Control of the Epidemic of Novel Coronavirus Pneumonia of the Chinese Preventive Medicine Association (2020) An update on the epidemiological characteristics of novel coronavirus pneumonia (COVID-19). Zhonghua Liu Xing Bing Xue Za Zhi 41(2): 139-144.

15. Guo Q, Li M, Wang C, Wang P, Fang Z, (2020) Host and infectivity prediction of Wuhan 2019 novel coronavirus using deep learning algorithm. bioRxiv.

16. Ji W, Wang W, Zhao X, Zai J, Li X (2020) Cross-species transmission of the newly identified coronavirus 2019nCoV. J Med Virol 92(4): 433-440.

17. Jiang S, Shi ZL (2020) The first disease X is caused by a highly transmissible acute respiratory syndrome coronavirus. Virol Sin: 1-3.

18. Yadav PD, Potdar VA, Choudhary ML, Nyayanit DA, Agrawal M, et al. (2020) Full-genome sequences of the first two SARS-CoV-2 viruses from India. The Indian journal of medical research 151(2\&3): 200-209.

\section{Epidemiology International Journal}

19. Tamura K, Nei M (1993) Estimation of the number of nucleotide substitutions in the control region of mitochondrial DNA in humans and chimpanzees. Mol Biol Evol 10(3): 512-526.

20. Kimura M (1980) A simple method for estimating evolutionary rate of base substitutions through comparative studies of nucleotide sequences. J Mol Evol 16(2): 111-120.

21. Kumar S, Stecher G, Li M, Knyaz C, Tamura K (2018) MEGA X: Molecular Evolutionary Genetics Analysis across computing platforms. Mol Biol Evol 35(6): 15471549.

22. Lu R, Zhao X, Li J, Niu P, Yang B, et al. (2020) Genomic characterization and epidemiology of 2019 novel coronavirus: implications for virus origins and receptor binding. Lancet 395(10224): 565-574.

23. Wu F, Zhao S, Yu B, Chen YM, Wang W, et al. (2020) A new coronavirus associated with human respiratory disease in China. Nature 579(7798): 265-269.

24. Zhang YZ, Holmes EC (2020) A Genomic Perspective on the Origin and Emergence of SARS-CoV-2. Cell 181(2): 223-227.

25. Wrapp D, Wang N, Corbett KS, Goldsmith JA, Hsieh CL, et al. (2020) Cryo-EM structure of the 2019-nCoV spike in the perfusion conformation. Science 367(6483): 12601263.

26. South China Agricultural University: Pangolin May Be a Potential Intermediate Host of New Coronavirus.

27. Xiao K, Zhai J, Feng Y, Zhou N, Zha ng X, et al. (2020) Isolation and Characterization of 2019-nCoV-like Coronavirus from Malayan Pangolins. BioRxiv.

28. Lin XD, Wang W, Hao ZY, Wang ZX, Guo WP, et al. (2017) Extensive diversity of coronaviruses in bats from China. Virology 507: 1-10.

29. Lee A (2020) Wuhan novel coronavirus (COVID-19): why global control is challenging?. Public health 179: 1-2.

30. India COVID-19 update.

31. Donald Trump casts doubt on Chinese coronavirus figures. 